\title{
Harri Veivo
}

\section{Edistyksen mutkaisella polulla}

Kun luennoin vuosituhannen vaihteessa semiotiikan historiasta, perehdyin kirkkoisä Augustinuksen tulkinnan teoriaan. Erimielisyydet Raamatussa kerrottujen tapahtumien merkityksestä jakoivat kirkkoa 400-luvulla. Augustinus yritti ratkaista nämä ongelmat kehittämällä tulkinnan metodin, joka ei jättäisi sijaa ristiriidoille. Ei ole yllättävää, että erimielisyyksiä esiintyy edelleen. Augustinus päätyi toteamaan, että tulkinnassa on viime kädessä otettava huomioon kaikki maailmaa koskeva tieto. Toisin sanoen tulkinnasta tuli päättymätön projekti.

Tulkinta ei enää tunnu olevan kirjallisuudentutkimuksessa keskeisessä asemassa. Tulkinnan asemesta tutkijat esittävät "luentoja" ("reading"). Tämä sanaston muutos ilmentää tutkimuksen tavoitteiden ja käytäntöjen siirtymää, joka saattaa helposti jäädä huomaamatta. Tulkinnan horisonttina on tekstin kokonaisuus, joka yritetään kattaa mahdollisimman hyvin (samalla toki tietäen, että tuo horisontti pakenee lukijaa); tulkintahakuisessa tutkimuksessa teos on arvomaailman ytimessä. Luennassa tyydytään osaan tekstiä, ja tuo osa pyritään saamaan osaksi argumentointia, joka koskee laajempaa teoreettista tai historiallista ongelmakenttää. Teos ei ole enää keskiössä, vaan pikemminkin yksi osanottaja moniäänisessä dialogissa. Tämä painopisteen siirtymä liittyy toiseen muutokseen, joka näkyy myös tutkimuksen retoriikassa.

Viime vuosina on tullut varsin yleiseksi tavaksi puhua kirjallisuudentutkimuksen uusista paradigmoista "käänteen" ("turn") metaforan avulla. Käänteet ovat seuranneet toisiaan nopeaan tahtiin, ja niiden puolesta on usein argumentoitu varsin aggressiivisesti. Voisi ajatella, että tie on käynyt varsin mutkikkaaksi. Niinhän se tavallaan onkin kuka voi väittää pystyvänsä keskustelemaan pätevästi kaikista tutkimuksen markkinoilla tarjolla olevista käänteistä? Paradoksaalisesti käänteiden retoriikan taustalla vaikuttaa kuitenkin kaksi tekijää, jotka perustuvat varsin suoraviivaisiin oletuksiin.

Käänteiden retoriikka on osa modernia ajattelua, jossa tieteen oletetaan edistyvän. Käänne on aina käänne kohti parempaa ja pois ajattelumallista, jonka selitysvoima on kuihtunut. Käänne ajatellaan tyypillisesti oikaisuliikkeeksi edistyksen polulla.

Toinen tekijä on käänteen retoriikan tehtävä tutkimuksen proosallisissa puitteissa, eli taistelussa rahoituksesta. Uusi paradigma, joka on käänne kohti parempaa, on tietenkin valttikortti tässä pelissä. Etenkin jos sen voi kytkeä kirjallisuudentutkimusta "kovempana" pidettyyn tieteenalaan. On myös suotavaa, että käänne edustaa maailmalla uutta tutkimussuuntausta, jonka maahantuojana rahoitushakemuksen tekijä voi 
esiintyä. Kansallinen modernisaation projekti ja suomalainen insinööriusko kohtaavat toisensa käännerahoituksen kielipelissä.

Näiden ehtojen vallitessa tulkinta ei ole kiinnostava tavoite. Edullisempaa on käyttää luentoja uusien teorioiden palveluksessa.

Kirjallisuus on tietenkin aina ollut tekemisissä uusimpien - kaikkien - tieteenalojen kanssa, eikä tutkimus voi olla huomioimatta niitä. Kirjallisuuden kieli kuuluu samaan jatkumoon kuin tieteen kieli, jonka peili tai pilkka se voi olla. Voidaan myös ajatella, että jokainen uusi luenta rikastuttaa teosta, läpivalaisee siitä osan, jonka juuri luennan taustalla vaikuttava teoria tekee näkyväksi. Käänteet ovat tämän rikkauden edellytys. Mutta kuka muistaa kaikki nämä luennat? Edistyksen mutkainen polku muuttu helposti unohduksen valtatieksi.

Ehkä edistyksen vaaliman insinöörihahmon rinnalle pitäisi nostaa toisenlaisia esikuvia. Harva meistä sekuläärin maailman asukkaista kaipaa takaisin kirkonmiesten hallitsemaan Augustinuksen aikaan. Mutta olisiko mahdotonta ajatella, että pieni ja tehokas insinöörihiiri asuu suuren ja harmaan kirjastonorsun sisällä? Että edistysusko palvelee kulttuurin muistia? 